\title{
PENDAMPINGAN (KONSELING) PASTORAL KEPADA ORANG YANG SULIT MENGAMPUNI
}

\author{
Eleven Louis Sihotang \\ Sekolah Tinggi Diakones HKBP Balige \\ eleven_sihotang@yahoo.co.id
}

\begin{abstract}
This article offers a model of pastoral counseling assistance for someone who is difficult to forgive and accept dark events. The model proposed in this paper is by building sympathetic relationships, assistance is carried out using the empty chair technicque and religious facilities. The type of research used in this paper is literature or literature study. The findings of this paper show that someone can forgive and accept dark events by imitating Jesus.
\end{abstract}

Key Words: Pastoral Care, Accepting, Forgiving

\begin{abstract}
Abstrak
Artikel ini menawarkan model pendampingan konseling pastoral terhadap seseorang yang sulit untuk mengampuni dan menerima peristiwa yang kelam. Model yang diajukan dalam tulisan ini yaitu dengan cara membangun hubungan yang simpati, mendampingi seseorang untuk mengakui dan menerima kondisi yang dialami. Pendampingan ini dilakukan dengan menggunakan teknik kursi kosong dan sarana religious. Jenis penelitian yang digunakan dalam tulisan ini adalah studi literature. Adapun temuan tulisan ini adalah seseorang dapat mengampuni dan menerima peristiwa kelam dengan cara meneladani sikap pengampunan dari Yesus.
\end{abstract}

Kata Kunci: Pendampingan Pastoral, Menerima dan Mengampuni

\section{PENDAHULUAN}

Di tengah-tengah dunia sekarang ini, banyak sekali terjadi peristiwa atau kejadian yang mengganggu keamanan, kenyamanan dan kedamaian manusia. Berbagai bencana alam, perang, kekerasan, demonstrasi, konflik SARA, tindakan-tindakan kriminal dan kecelakaan dapat meninggalkan penderitaan, kedukaan dan trauma bagi mereka yang mengalaminya. Sadar atau tidak sadar, kejadian-kejadian tersebut memengaruhi kehidupan manusia yang adalah kompleks dan multidimensional. Selain itu, manusia juga dikenal sebagai makhluk holistik ${ }^{1}$ dan makhluk keberjumpaan ${ }^{2}$ yang selalu memberadakan diri bersama dengan sesuatu atau seseorang lain. Dalam interaksinya dengan sesama, manusia akan menghadapi berbagai sikap, karakter, life style serta situasi yang berbeda-beda. Di satu sisi, kepelbagaian itu dapat mendatangkan kebahagiaan, kegembiraan/sukacita, akan tetapi di sisi lain dapat menimbulkan kebencian, kedukaan, sakit hati, luka batin, dendam bahkan kepahitan yang akhirnya menyebabkan penderitaan. Jika penderitaan tersebut

\footnotetext{
${ }^{1}$ Totok S Wiryasaputra, Pengantar Konseling Pastoral (Yogyakarta: Diandra, 2014). 39
}

${ }^{2}$ Ibid. 51 
tidak segera diatasi, maka dapat berdampak negatif bagi kesehatan fisik dan psikis manusia. Tentunya kerugian-kerugian lain dapat muncul yang berdampak pada terganggunya aktivitas sehari-hari baik sebagai individu dan juga dalam interaksinya dengan orang lain di sekitarnya.

Sebagai ImagoDei (citra/gambar Allah), manusia mempunyai kemampuan untuk hidup, mencipta, berfikir dan merasakan. Di samping itu, manusia diciptakan sebagai makhluk mulia yang dianugerahi aspek fisik (jasmani), mental (berfikir, merencanakan dan membedakan diri), sosial (berelasi dengan yang lain) dan spiritual (berelasi dengan Sang Pencipta). Namun tidak dapat dipungkiri bahwa penderitaan, penyakit, dukacita, kemalangan bahkan peristiwa kelam/buruk/traumatis lainnya dapat menimpa kehidupan manusia kapan saja dan dimana saja. Peristiwa-peristiwa kelam tersebut dapat merubah pribadi seseorang secara perlahan-lahan maupun tiba-tiba. Kematangan psikis dan kemampuan penyesuaian (adjustment) yang baik akan mempengaruhi kemampuan seseorang menghadapi peristiwa kelam dalam hidupnya. Manusia adalah makhluk vulnerable (mudah terserang, rentan, terluka) sehingga membutuhkan penolong atau pendamping dalam menghadapi persoalan dan goncangan dalam hidupnya. Ketika peristiwa kelam terjadi maka manusia dapat jatuh dalam kebencian, keterasingan, kepahitan yang akhirnya merusak kepribadian dan relasinya dengan sesama bahkan dengan Tuhan Sang Pemelihara Kehidupan. Pengalaman pahit yang dialami membuatnya sulit mengampuni pribadi atau komunitas tertentu yang dianggap terlibat langsung atau tidak langsung dalam penderitaannya. Dalam konteks seperti ini sangat diperlukan pendampingan pastoral yang dapat mengarahkan manusia dengan problemanya terbuka untuk mengampuni sampai kepada tahap menerima (acceptance) akan peristiwa kelam yang dialaminya. Seseorang yang tidak mampu mengampuni mereka yang telah menyakitinya, sesungguhnya dia sendirilah yang menderita ${ }^{3}$. Orang-orang yang tidak dapat mengampuni adalah mereka yang terpenjara secara psikologis dan spiritual. Orang-orang yang demikian sangat memerlukan pertolongan/pendampingan. Pertolongan/pendampingan dapat diberikan oleh Gereja melalui pendampingan pastoralnya. Dengan demikian yang menjadi pertanyaan adalah pertama, bagaimanakah urgensi pendampingan pastoral agar dapat mengampuni dan mampu menerima peristiwa kelam? Kedua, sejauh manakah dampak pendampingan pastoral hingga seseorang dapat mengampuni dan menerima peristiwa yang kelam?

\section{METODE PENELITIAN}

Tulisan ini menggunakan metode penelitian literatur atau kepustakaan. Permasalahan dalam tulisan ini dianalisis dan dijawab berdasarkan bahan pustaka yang mendukung topik tulisan

\footnotetext{
${ }^{3}$ Harriet Hill, Healing the Wounds Of Trauma: How The Church Can Help (Philadelphia: American Bible Society,
} 2016). 109. 
serta berkaitan dengan pokok bahasan. Adapun pustaka yang digunakan adalah buku cetak dan buku eletronik.

\section{HASIL DAN PEMBAHASAN}

\section{Urgensi Pendampingan Pastoral agar dapat Mengampuni dan Mampu Menerima Peristiwa} Kelam

Kata pendampingan pastoral terdiri dari dua kata yaitu pendampingan dan pastoral. Dalam Kamus Besar Bahasa Indonesia (KBBI) kata pendampingan berartiproses, cara, perbuatan mendampingi atau mendampingkan ${ }^{4}$. Kata pendampingan berasal dari kata kerja mendampingi yang merupakan kegiatan menolong orang lain sebab perlu didampingi. Sementara orang yang mendampingi disebut sebagai pendamping. Antara pendamping dan yang didampingi mempunyai interaksi sejajar dan adanya hubungan timbal-balik. Aart van Beek berpendapat bahwa pendampingan adalah kegiatan kemitraan, bahu-membahu, menemani, membagi/berbagi dengan tujuan saling menumbuhkan dan mengutuhkan ${ }^{5}$. Dalam hal ini berarti antara pendamping dan yang didampingi sama-sama mempunyai kemampuan atau daya untuk bertumbuh dan berkembang sesuai dengan kapasitasnya masing-masing.

Kata selanjutnya adalah pastoral. Pastoral berasal dari kata "pastor" yang dalam bahasa Latin atau Yunani disebut poimen yang artinya gembala. Dalam tradisi kehidupan gerejawi secara tradisional, gembalamerujuk pada tugas pendeta yang menjadi gembala bagi jemaat atau dombadombanya. Dalam Alkitab, istilah "Gembala yang Baik" (Yoh. 10) merujuk kepada diri Yesus Kristus. Yesus digambarkan sebagai Gembala yang Baik yang bersedia memberikan pertolongan dan pengasuhan terhadap para pengikut-Nya dan orang-orang yang ditemui tanpa pamrih. Bahkan, puncak dari pertolongan dan kepedulian-Nya adalah dengan rela mengorbankan nyawa-Nya demi manusia yang dikasihi-Nya. Pelayanan yang diberikan Yesus merupakan tugas kemanusiaan yang sungguh teramat mulia. Melalui teladan tersebut, Yesus mengharapkan para pengikut-Nya dapat mengambil sikap dan pelayanan dalam kehidupan mereka. Mengacu pada tindakan pelayanan Yesus, tugas pastoral tidak hanya tugas atau monopoli para pastor atau pendeta akan tetapi merupakan tugas bagi setiap orang yang menjadi pengikut-Nya.

Dasar teologis dari pendampingan pastoral ialah inkarnasi Allah di dalam diri Yesus Kristus. Tuhan Allah yang menjelma menjadi manusia secara sempurna dalam Yesus Kristus (Yohanes 1:14). Dia satu-satunya Allah yang mengasihi (loving), memedulikan, mendampingi (caring), mendengarkan

\footnotetext{
4“Kamus Besar Bahasa Indonesia (KBBI)" (Jakarta: Balai Pustaka, 1996).

${ }^{5}$ Aart Van Beek, Pendampingan Pastoral (Jakarta: Gunung Mulia, 2015). 9
} 
(listening to), dan menyembuhkan (healing) ${ }^{6}$. Dengan demikian dasar teologi pendampingan pastoral bersifat Kristosentris yakni berpusat pada teladan Kristus. Pendampingan pastoral yang terjadi berdasarkan hubungan antara Yesus (Sang inkarnasi) sebagai manusia dengan sesama-Nya manusia.

Menurut Howard Clinebell, pendampingan pastoral adalah suatu jawaban terhadap kebutuhan setiap orang akan kehangatan, perhatian penuh, dukungan dan penggembalaan (pendampingan). Pendampingan pastoral merupakan ungkapan pendampingan yang bersifat memperbaiki (reparatif), yang berusaha memberi pemulihan dan kesembuhan bagi orang-orang yang sedang menderita gangguan fungsi dan kehancuran karena krisis ${ }^{7}$. Selain untuk menjawab kebutuhan-kebutuhan pribadi manusia, pendampingan pastoral juga muncul untuk merespon persoalan-persoalan sosial dalam komunitas masyarakat.Pendampingan pastoral tumbuh dan berkembang atas semangat, sikap dan tindakan saling memedulikan sesama yang mengalami krisis kehidupan. Hal ini telah ditunjukkan Allah pada seluruh ciptaan-Nya. Sejak mula pertama Allah telah menunjukkan kepedulian (care) atas manusia dan ciptaan lainnya yang nampak dari sejak penciptaan, pemeliharaan, penghukuman, pemulihan (restorasi) bahkan sampai pada rekonsiliasi yang nyata lewat inkarnasi Allah dalam pribadi dan karya Yesus Kristus. Pendampingan pastoral disebut juga sebagai pendampingan inkarnasional ${ }^{8}$ yang menggambarkan karakter Allah yakni mengasihi, menertibkan, menciptakan, menghidupkan, menyelamatkan, memedulikan, memperhatikan, merawat, mendampingi, mengubah, menumbuhkan, mengampuni dan sebagainya. Dengan demikian dasar dari pendampingan pastoral adalah Missio Dei atau misi Allah dan tidak hanya dapat dilakukan oleh jabatan seorang manusia yaitu pastor atau gembala atau pendeta tetapi semua orang percaya.

Di tengah-tengah dunia dengan persoalan kehidupan yang semakin kompleks maka pelayanan pendampingan pastoral merupakan suatu pelayanan yang urgen dilayankan Gereja (orang percaya) baik secara perorangan maupun secara komunitas. Pendampingan pastoral sebagaimana konseling pastoral merupakan integrasi dari bidang teologi dan psikologi yang digunakan dalam memahami individu atau kelompok masyarakat. Dengan demikian, pemahaman akan hakikat manusia dengan kebutuhan-kebutuhannya menjadi sesuatu yang penting untuk diketahui. Di samping itu, titik tolak dari pendampingan pastoral kepada individu atau kelompok adalah berdasarkan perilaku yang tampak dalam interaksinya dengan sesama dan lingkungannya.

Setiap individu memiliki perilaku yang unik dan khas. Perilaku mirip sidik jari, tidak ada yang sama. Dengan kata lain, tidak ada individu yang memiliki perilaku yang sama persis ketika menghadapi situasi atau stimulus yang sama. Namun demikian, bukan berarti tidak ada batas-batas antara perilaku yang wajar dengan perilaku yang tidak wajar. Dikatakan perilaku yang sehat atau wajar

\footnotetext{
${ }^{6}$ Totok S Wiryasaputra, Pendampingan Pastoral Orang Sakit (Yogyakarta: Kanasius, 2016). 32

${ }^{7}$ Howard Clinebell, Tipe-Tipe Pendampingan Pastoral Dan Konseling Pastoral (Jakarta: Gunung Mulia, 2002). 60 ${ }^{8}$ Wiryasaputra, Pengantar Konseling Pastoral. 8
} 
bila perilaku tersebut merupakan respon yang sesuai serta membuat individu menjadi lebih berkembang dan matang. Sedangkan perilaku dianggap tidak sehat/tidak wajar adalah bila perilaku tersebut tidak lagi sesuai dengan situasi yang dihadapi bahkan membuat individu menjadi semakin mengerut dan terhambat ${ }^{9}$. Jadi sehat atau tidaknya perilaku seseorang dapat dinilai dari pemberian responnya akan sesuatu sesuai atau tidak.

Perilaku individu ditentukan oleh cara pandangnya terhadap realita dan dunia. Misalnya pengalaman kehidupan seorang perempuan muda yang patah hati karena ditinggal mati oleh kekasihnya. Sebelum ia ditinggal pergi, perempuan muda tersebut dikenal sebagai perempuan yang periang, bersahabat dan optimis dalam kesehariannya. Akan tetapi, pengalaman hidup yang ia alami membuatnya menjadi seorang yang suka menyendiri (mengurung diri), pendiam dan kehilangan semangat hidup. Dia menilai bahwa dirinya adalah seorang perempuan yang paling malang dan dunia sangat kejam kepadanya. Perilakunya berubah oleh karena dia menilai pengalaman hidupnya yang kelabu. Perempuan muda tersebut membutuhkan penolong atau pendamping sehingga ia dapat menerima dan mengalami (menghayati) kedukaannya secara utuh dan penuh. Kehadiran seorang pendamping diharapkan dapat menopang dalam menumbuhkan pengharapan yang baru bagi perempuan muda tersebut.

Banyak hal yang menyebabkan perilaku seseorang berubah. Salah satu penyebabnya ialah adanya pengalaman pahit atau peristiwa kelam yang melukai batin dan meninggalkan kedukaan yang mendalam dalam diri seseorang. Sebagai dampak dari kedukaannya dapat terlihat dari perilakunya yang tidak dapat mengampuni dirinya sendiri maupun orang lain. Wujud dari ketidak-bersediaannya untuk mengampuni dapat terlihat dari sikapnya yang sering merasa sedih, merasa tegang, mudah tersinggung, kecewa yang berlebihan kepada kelompok atau komunitas tertentu. Selain itu perilaku yang sulit mengampuni juga mempengaruhi kesehatan fisik seseorang. Contohnya tukak lambung (adanya luka pada lambung), anorexia nervosa (adanya gangguan makan), migraine (pusing kepala yang sangat nyeri) dan gangguan psikis lainnya.

Perilaku sulit mengampuni adalah perilaku yang terkait dengan aspek mental manusia. Aspek mental berkaitan dengan kognisi (pikiran-cipta), afeksi (emosi, perasaan baik positif maupun negatif rasa), konasi (kehendak, motivasi - karsa), dan psikomotorik (gerak - karya) ${ }^{10}$. Ketika seseorang dalam keadaan tidak dapat atau sulit mengampuni maka akan berpengaruh kepada kognisinya. Pikirannya akan acap kali terganggu dan sulit untuk berkonsentrasi sehingga tidak dapat mencipta atau melahirkan ide atau gagasan-gagasan yang baru. Ketidak-mampuan mengampuni juga mempengaruhi afeksi, yang mana keadaan emosi seseorang menjadi meletup-letup atau tidak stabil. Emosinya

\footnotetext{
${ }^{9}$ Siswanto, Kesehatan Mental: Konsep, Cakupan Dan Pengembangannya (Yogyakarta: Gunung Mulia, 2007). 170 ${ }^{10}$ Wiryasaputra, Pendampingan Pastoral Orang Sakit. 8
} 
bagaikan gunung yang siap-siap mengeluarkan laharnya yang panas dan bisa mengenai siapa saja yang di sekitarnya. Tentu saja, ketidak-mampuan mengampuni akan mempengaruhi konasi yaitu kehendak, motivasi dan karsa. Seseorang yang tidak dapat atau sulit mengampuni menjadi seorang yang pesimis, motivasi, niat dan keinginan yang rendah. Hal yang terakhir yang tak kalah pentingnya bahwa pribadi yang sulit atau tidak dapat mengampuni akan berpengaruh pada psikomotoriknya. Ketidak-mampuan mengampuni mempengaruhi gerakannya menjadi sedikit lamban. Selain itu, dia akan menjadi pribadi yang kaku dan tidak berdaya untuk berkarya.

Secara kasat mata, perilaku sulit mengampuni sepertinya persoalan psikologis yang sederhana. Akan tetapi jika ditelusuri, perilaku tidak atau sulit mengampuni tersebut sangat mempengaruhi keseluruhan aspek kehidupan manusia secara holistik. Ketika perilaku sulit atau tidak mengampuni tidak ditangani secara serius, sebenarnya pribadi yang mengalaminya sedang menuju kepada kehancuran dan kelumpuhan secara perlahan-lahan. Selain berdampak terhadap aspek fisik, perilaku sulit atau tidak mampu mengampuni juga akan mempengaruhi aspek sosial dan spiritual dalam diri seseorang. Perilaku seseorang yang sulit mengampuni akan berdampak dalam interaksinya dengan sesamanya dan cenderung berdampak juga dalam relasinya dengan Sang Pencipta.

Pendampingan pastoral menjadi suatu pelayanan yang urgen dalam mendampingi mereka yang mengalami persoalan psikologis. Hal mendasar yang harus dimiliki oleh seorang pendamping pastoral adalah iman yang kokoh di dalam Dia, Allah, Sang Konselor Sejati. Pendampingan pastoral merupakan upaya menghadirkan Allah di dalam perjumpaan pastoral ${ }^{11}$. Dengan kata lain, seorang pendamping pastoral harus mampu mengejawantahkan keberadaan Allah dalam proses pendampingan pastoral lewat tindakan memedulikan, memelihara dan memulihkan sesama. Allah hadir dalam interaksi manusia terlebih lagi dalam pertolongan yang sungguh-sungguh. Dengan demikian pendamping pastoral perlu menyadari bahwa kehadirannya bersama dengan orang yang didampingi adalah dalam rangka menjalankan tugasnya sebagai manusia beriman menurut gambar Allah.

Pendampingan pastoral adalah pelayanan yang bersentuhan langsung dengan manusia sebagai dokumen hidup yang memiliki keunikan, kebutuhan, persoalan dan kemampuan berbeda-beda yang khas. Seorang pendamping pastoral perlu memiliki disiplin yang tinggi dan terlatih kaitannya dalam mendampingi. Dengan begitu dia mampu memberadakan dirinya di hadapan orang yang didampingi dan menjadi teman seperjalanan dalam melalui rintangan atau persoalan kehidupan. Selain itu, pendamping pastoral juga harus memiliki pendidikan konseling yang baik yaitu pendidikan yang diawasi baik secara akademis maupun secara klinis. Dengan memiliki pendidikan yang baik, maka ia dapat memaksimalkan kemampuannya menjadi suatu alat penyembuhan secara khusus penyembuhan psiko spiritual. Selain pendidikan, keterampilan dan sikap dasar juga harus dimiliki oleh pendamping

\footnotetext{
${ }^{11}$ Beek, Pendampingan Pastoral. 41
} 
pastoral. Adapun keterampilan dasar yang harus dimiliki seorang pendamping pastoral adalah mendengarkan, memperjelas, memantulkan, menafsirkan, mengarahkan, meringkas, memusatkan, memberi informasi, mengajukan pertanyaan dan menantang. Sedangkan sikap dasar yang harus dimiliki oleh pendamping pastoral adalah empati, tertarik, percaya pada proses, terbuka, spontan, tulus hati, kenal diri, universalistik dan otonom. Dengan memiliki keterampilan dan sikap dasar tersebut, proses pendamping pastoral akan dapat menjawab kebutuhan-kebutuhan mereka yang didampingi.

Menurut Aart van Beek dalam bukunya Pendampingan Pastoral, ada enam fungsi pendampingan pastoral. Fungsi pendampingan tersebut merupakan tujuan operasional yang hendak dicapai dalam memberikan pertolongan kepada orang lain. Adapun fungsi tersebut adalah membimbing, mendamaikan/memperbaiki hubungan, menopang/menyokong, menyembuhkan dan memberdayakan.

\section{Dampak Pendampingan Pastoral agar dapat Mengampuni dan Mampu Menerima Peristiwa yang Kelam}

Mengampuni berasal dari kata ampun yang artinya pembebasan dari tuntutan karena melakukan kesalahan atau kekeliruan, maaf. Sedangkan mengampuni berarti memberi ampun, memaafkan atas kesalahan $^{12}$. Melakukan kesalahan merupakan hal yang manusiawi, namun memaafkan adalah perbuatan ilahi (agung). Mengampuni dan diampuni merupakan hal yang banyak ditemui dalam interaksi antar manusia. Ada banyak orang yang mudah mengampuni akan tetapi tidak sedikit juga orang yang sulit mengampuni. Hal mengampuni bukan saja terkait dengan kesalahan orang lain tetapi juga kesalahan diri sendiri. Selain mengampuni orang lain, banyak orang yang terjebak dalam persoalan psikologis saat ia tidak dapat mengampuni dirinya sendiri. Mengampuni seseorang berarti menyadari bahwa orang lain sudah berbuat salah dan mengakui perasaan sakit yang diakibatkan oleh perilaku orang lain tersebut. Sedangkan mengampuni diri sendiri adalah dengan menyadari dan melihat jauh ke dalam diri pribadi hal yang membuatnya kecewa, terluka, bersedih dan mengganggap bahwa persoalan yang ada disebabkan oleh dirinya. Jika orang-orang tersebut berada dalam situasi yang tidak mampu mengampuni maka hubungan interaksinya dengan orang lain akan terganggu.

Pengampunan tidak terjadi secara langsung. Mengampuni - pengampunan secara penuh memerlukan waktu yang cukup lama. Bisa saja pengampunan telah diberikan akan tetapi karena suatu situasi tertentu mengingatkan kembali perasaan sakit dari kesalahan tersebut. Jika keadaan demikian terjadi, berarti masih diperlukan keterbukaan dan kesungguhan hati untuk mengampuni sepenuhnya. Ketika seseorang mengampuni bukan berarti dia melupakan segala sakit hatinya. Dengan mengampuni seseorang bukan berarti bisa langsung percaya kepada orang yang telah membuatnya kecewa atau sakit hati tersebut. Pengampunan yang diberikan bukan serta merta membuat seseorang berubah.

\footnotetext{
12“Kamus Besar Bahasa Indonesia (KBBI)." 34
} 
Kalaupun ada perubahan, rasa percaya telah rusak dan dibutuhkan waktu untuk membangun kepercayaan itu kembali.

Dalam Alkitab, Allah telah mengajarkan orang percaya untuk mampu mengampuni. Secara manusiawi, mengampuni atau memaafkan adalah hal yang sulit dilakukan. Apalagi jika hal itu menyangkut pengalaman atau peristiwa yang mengganggu keseimbangan hidup. Maka mengampuni pengampunan sulit diberikan kepada orang yang dianggap bersalah. Terkadang, seseorang tidak mau mengampuni sebelum orang yang bersalah telah meminta maaf lebih dahulu. Atau ada juga yang mau melihat lebih dahulu bahwa orang tersebut telah berubah dan kemudian dia mengampuni atau memaafkan. Akan tetapi perlu diingat, hanya Allah saja yang dapat memampukan setiap orang percaya untuk mengampuni (1 Petrus 2:24). Mengampuni sepenuhnya dapat dilakukan jika dia bersedia membawa segala sakit hati, kekecewaan, kesedihan ke bawah salib Yesus Kristus dan melepaskannya. Saat Yesus menyembuhkan perasaan sakit, maka pada saat itu akan ada kuasa atau kemampuan untuk mengampuni orang-orang yang menyakiti hati. Dalam Perjanjian Baru, penekanan tentang pengampunan dikaitkan dengan karya penebusan Tuhan Yesus. Pengampunan didasarkan pada pekerjaan Kristus yang mendamaikan dan menebus dan hal itu merupakan tindakan anugerah semata (1 Yohanes 1:9). Kristus menyerukan bahwa dalam nama-Nya berita tentang pertobatan dan pengampunan dosa harus disampaikan kepada segala bangsa (Lukas 22:47). Pengampunan terjadi hanya karena Allah sudi mengampuni. Manusia yang ingin menerima pengampunan harus bertobat, sedangkan yang tidak mau bertobat tidak memperoleh pengampunan. Orang berdosa yang diampuni harus juga mengampuni orang lain ${ }^{13}$.

Yesus adalah teladan setiap orang percaya untuk mengampuni. Mengampuni orang merupakan bagian integral dari pelayanan penyembuhan Yesus $^{14}$. Lewat pengampunan yang Ia berikan mau menunjukkan kepada orang-orang bagaimana memberi dan menerima pengampunan. Hanya jika seseorang mengalami cinta kasih pengampunan Tuhan atas segala dosa dan salah, maka dia akan dimampukan untuk mengampuni. Yesus bersedia mengampuni orang-orang yang tidak merasa bersalah atas kejahatan yang sudah diperbuatnya. (Roma 5:8). Di atas kayu salib, Yesus berkata "Ya Bapa, ampunilah mereka, sebab mereka tidak tahu apa yang mereka perbuat.” Lukas 23:34). Penderitaan, siksaan yang dialami Yesus tidak sepatutnya Dia terima akan tetapi Ia mampu memberikan pengampunan bagi mereka yang telah memperlakukannya tidak manusiawi. Mengampuni seseorang bukan berarti bahwa mereka tidak akan dihukum, sebab mereka telah berbuat salah ${ }^{15}$. Dengan mengampuni berarti mengizinkan Tuhan untuk menghakimi dan membalasnya (Roma 12:1921) karena penghakiman dan penghukuman itu sendiri hanya milik Allah.

\footnotetext{
${ }^{13}$ Dianne Bergant Robert J. Karris (editor), Tafsir Alkitab Perjanjian Baru (Yogyakarta: Kanasius, 2002). 231

${ }^{14}$ Bridget Mary Meehan, Kuasa Penyembuhan Doa (Yogyakarta: Kanasius, 2006). 73

${ }^{15}$ Harriet Hill, Healing the Wounds Of Trauma: How The Church Can Help (Philadelphia: American Bible Society, 2016). 108
} 
Manusia baru dapat mengampuni (memaafkan) sesamanya, kalau ia telah mampu mencerna dan menyelesaikan semua perasaan emosi problematis yang disebabkan oleh sesama mereka itu ${ }^{16}$. Hal itu hanya dapat dilakukannya dengan membawa segala persoalannya di bawah salib Yesus. Dengan kemampuannya sendiri, dia akan pasang surut antar mengampuni dan mengingat-ingat kembali kesalahan orang lain, tetapi di dalam terang kuasa pengampunan Yesus, dia dapat dipulihkan. Dengan demikian, dia sedang membangun masa depan yang lebih baik bagi hidupnya dan hidup orang yang dimaafkannya. Jika tidak demikian, maka relasi dengan sesama akan terganggu, demikian juga relasi dengan Tuhan Allah. Dengan kata lain, bukan hanya tidak adanya pengampunan yang merintangi kita dan Allah, hal itu juga merusak hubungan kita dengan orang lain.

Pada umumnya, manusia akan sulit melupakan peristiwa kelam yang menghampiri kehidupannya secara tiba-tiba. Peristiwa kelam dapat berupa kematian yang mendadak dan tidak wajar, misalnya kematian akibat kecelakaan lalu lintas, kematian karena sakit-penyakit, pembunuhan, mutilasi. Selain itu kehilangan orang yang dicintai karena bencana alam atau bencana lainnya atau dicuri orang yang tidak bertanggung jawab. Peristiwa kelam berupa kedukaan akibat kehilangan sesuatu yang sangat dicintai atau seseorang yang sangat dikasihi dapat menyebabkan perkembangan terganggu, krisis, trauma dan kehilangan ambigu (ambiguous loss). Ketika seseorang mengalami krisis, trauma, kehilangan ambigu dan tidak dapat mengelola keadaan psikologisnya dapat menyebabkan depresi. Depresi yang berkepanjangan dapat menyebabkan seseorang menjadi stress bahkan bisa mengarah ke gangguan jiwa lainnya. Jika tidak dapat mengelola kedukaan atau kehilangan yang berlarut-larut, bisa saja terjadi pelampiasan emosi yang salah. Orang-orang di sekitar bisa ikut menderita khususnya orang-orang terdekat atau keluarga.

Bagaimana usaha agar seseorang dapat mengampuni dan mampu menerima peristiwa kelam dalam kehidupannya? Pendampingan pastoral adalah salah satu pelayanan yang dapat memberi pertolongan kepada mereka yang mengalami persoalan psikologis tersebut. Pendampingan pastoral adalah integrasi dari pengetahuan teologi dan psikologi, maka pendamping pastoral harus memahami dan menguasai kedua bidang ilmu tersebut. Umumnya orang yang memerlukan pendampingan pastoral adalah mereka yang mempunyai masalah psikologisnya yang akhirnya berdampak kepada spiritualitas atau kerohaniaannya. Dalam pendampingan pastoral pengampunan memainkan peranan penting. Pengampunan adalah kuasa - kuasa Allah - yang membebaskan manusia dari segala sesuatu yang memberatkan hidupnya, seperti dosa, kemarahan, kebencian, kegagalan, keputus-asaan, kekecewaan dan sebagainya ${ }^{17}$. Jika hal-hal tersebut tidak diselesaikan dari kehidupan manusia maka kepahitan, kemarahan, permusuhan, dan konflik dengan orang lain yang tidak akan terselesaikan.

\footnotetext{
${ }^{16}$ Abineno J.L. Ch, Pelayanan Pastoral Kepada Orang Berduka (Jakarta: Gunung Mulia, 2007). 116

${ }^{17}$ Ibid. 113
} 
Pendampingan pastoral agar orang dapat mengampuni dan mampu menerima peristiwa yang kelam adalah sebagai berikut:

a. Membangun hubungan yang simpatik.

Langkah pertama yang penting dalam memulai pendampingan adalah membangun hubungan yang simpatik dengan yang didampingi. Orang-orang yang mengalami persoalan terkadang kurang terbuka menerima orang lain apalagi untuk mengisahkan pengalaman pahitnya. Bisa saja dia beranggapan bahwa pendamping hanya membuka kembali kesedihan dan kepahitan dalam hidupnya. Dalam hal ini pendamping haruslah seorang yang berkepribadian menarik, menyenangkan dan pintar dalam memulai percakapan dengan tidak menyinggung perasaan yang didampingi. Pendamping pastoral juga adalah seorang yang rendah hati dan dengan kesabaran yang penuh mampu mendengarkan setiap keluhan orang yang didampingi. Dalam kontak pertama, orang yang didampingi perlu diberi pengharapan bahwa pendekatan atau proses pendampingan perlu dicoba. Jika hubungan simpatik telah dibangun, maka pendampingan selanjutnya akan lebih langgeng.

Hal lain yang perlu dimiliki oleh pendamping pastoral adalah sehat secara holistik. Artinya secara fisik, mental, sosial dan spiritual dia sehat sehingga diharapkan mampu menolong orang lain. Jika tidak demikian, tentu pendampingan yang dilakukan kurang maksimal. Proses pendampingan pastoral adalah proses bertumbuh dan berkembang secara bersama antara orang yang didampingi dengan pendamping. Dengan kata lain, pendamping hanyalah sebagai pengarah yang menolong orang yang didampingi untuk melihat potensi dan daya yang ada dalam dirinya untuk digunakan memecahkan masalahnya.

b. Mendampingi untuk sampai kepada pengakuan - mengakui.

Pendampingan pastoral adalah suatu proses percakapan antara pendamping dengan orang yang didampingi dimana Pendamping hadir secara utuh dan penuh. Melalui perjumpaan yang berlangsung, pendamping menggunakan keterampilan dan sikap dasar yang dimilikinya untuk menolong yang didampingi mengakui kepahitan, kemarahan, kekecewaan, permusuhan yang sedang ia alami. Pengakuan ini dapat dilakukan dengan meminta orang yang didampingi mengutarakan ceritanya secara verbal atau juga melalui doa-doa yang dipanjatkan. Selain itu, pengakuan akan rasa sakit hati dan kemarahan dapat juga dicurahkan melalui tulisan dengan menguraikan semua perasaannya. Setelah itu, tulisan tersebut dapat dibakar atau kertasnya disobeksobek atau diletakkan di bawah salib Yesus yang akan mengangkat semuanya. Pendamping pastoral sebaiknya mengarahkan yang didampingi, untuk mengakui perasaan yang menyesakkannya kepada Sang Penyembuh yang Ajaib. Yesus akan selalu setia menyendengkan telinga bagi mereka yang berseru kepada-Nya. Dalam hal ini seorang pendamping pastoral harus 
mendengarkan secara empati dan dengan cermat melihat kebutuhan-kebutuhan yang didampingi. Apabila pendamping memberi kesempatan bagi yang didampingi untuk mengungkapkan emosinya secara penuh dan utuh dengan empati, maka fungsi pendampingan yang terjadi adalah menyembuhkan dan menopang.

c. Mendampingi untuk sampai kepada penerimaan (acceptance) - menerima.

Saat orang yang didampingi sudah mampu mengakui sepenuhnya bahwa ia sedang sakit hati, maka tugas pendamping pastoral adalah mendampingi dia untuk beberapa kali (sesuai kebutuhan/perkembangan yang didampingi) agar sampai kepada penerimaan akan situasinya. Penerimaan adalah kunci dari sebuah perubahan. Tanpa penerimaan akan sulit bagi seseorang mengampuni. Boleh jadi dia mengatakan telah mengampuni dan tidak sakit hati lagi, tetapi suatu waktu memunculkan kembali hal-hal yang masih terselip di hatinya.

Dari sekian banyak persoalan hidup, hal penting yang perlu dipahami adalah sejauh mana penerimaan (acceptance) seorang yang bermasalah akan persoalan yang dihadapinya. Peristiwa kelam yang mendukakan hati tentu sulit untuk dilupakan. Bukan hanya peristiwa tersebut yang sulit dilupakan tetapi khususnya orang-orang yang terkait dengan peristiwa tersebut. Oleh karena shock yang hebat dan ketidakterimaan akan peristiwa yang terjadi, seseorang dapat menciptakan permusuhan dengan orang-orang yang dianggap terlibat menjadi penyebab peristiwa. Untuk sampai kepada tahap penerimaan seutuhnya, seorang pendamping pastoral dituntut untuk mempunyai kesabaran yang tinggi dalam mendampingi sehingga yang didampingi dapat mengalami kembali persoalannya. Dengan demikian lewat proses pendampingan yang dilalui bersama, seorang yang didampingi atau ditolong untuk dapat menerima keadaannya.

Sebagaimana dipaparkan bahwa penerimaan adalah kunci dari perubahan, maka tanpa penerimaan seseorang tidak akan mungkin dapat mengampuni. Tekanan hidup yang berat dan pergumulan yang datang silih berganti akan dapat dilalui jika seseorang sudah sampai pada tahap penerimaan (acceptance) yang kemudian akan menggiringnya ke tahap pemulihan selanjutnya.

\section{d. Menggunakan model pendekatan atau teknik}

Melatih orang untuk dapat mengampuni membutuhkan suatu pendekatan atau teknik tertentu. Pendekatan yang digunakan bisa jadi perpaduan beberapa model yang memudahkan pendamping dalam mendampingi mereka yang sulit mengampuni. Selain mengungkapkan perasaan, yang didampingi juga dapat diarahkan untuk mengeluarkan semua unek-uneknya dengan cara katarsis ${ }^{18}$ atau juga dengan menggunakan media misalnya kursi kosong (empty chair). Model atau pendekatan phenomenologis/humanistik yang di dalamnya mencakup teknik kursi kosong dinilai berhasil untuk beberapa kasus tertentu. Saat orang yang bermasalah/yang didampingi tidak berani

\footnotetext{
${ }^{18}$ Katarsis adalah mencurahkan isi perasaan.
} 
mengutarakan langsung kekecewaan, kemarahannya kepada seseorang maka kursi kosong dapat menjadi representasi kehadiran orang yang dia benci atau dianggap bersalah. Dalam kursi kosong, yang didampingi membayangkan bahwa orang yang dibenci yang tidak dapat diampuni sedang duduk di sana. Atas arahan dari pendamping, persilahkan yang didampingi mengeluarkan kepenatan dalam hatinya. Pendamping perlu menjelaskan pada bagian awal proses pendampingan yang dilaksanakan dan tetap mengawasi proses pendampingan tersebut sampai selesai. Selain kursi kosong, dapat juga digunakan batu yang dilemparkan sekuat tenaga ke tengah-tengah danau atau sungai; memukul bantal atau batang pohon pisang. Hal yang penting adalah jangan sampai melukai orang yang didampingi, pendamping dan orang-orang di sekitarnya. Teknik tersebut dapat membantu orang yang didampingi mengeluarkan energi negatif (kemarahan/kebencian) yang menghambat dia untuk mengampuni.

\section{e. Gunakan Alkitab dalam pendampingan pastoral}

Penggunaan Alkitab dalam pendampingan pastoral dapat dilakukan dengan dua macam pendekatan yaitu pendekatan tradisional dan pendekatan dinamis. Pendekatan tradisional lebih berfokus pada nasihat dan teguran dengan menggunakan ayat-ayat Alkitab untuk mengarahkan yang didampingi memahami masalahnya. Sedangkan pendekatan dinamis artinya pendekatan yang mementingkan metafor atau ibarat atau simbolisme ${ }^{19}$. Perlu diingat bahwa pemberian nasihat atau penekanan akan ayat-ayat Alkitab sebaiknya digunakan pada bagian akhir dari proses pendampingan sehingga tidak ada kesan bagi yang didampingi bahwa si pendamping pastoral sedang berkhotbah. Ketidakcermatan dalam menggunakan Alkitab dalam pendampingan dapat mengganggu keseluruhan proses yang sudah berlangsung. Pendamping pastoral perlu hati-hati dalam menggunakan Alkitab dalam proses pendampingan. Hal ini sering terjadi pada pendamping pastoral yang juga adalah teolog. Proses pendampingan bukanlah khotbah untuk menobatkan orang yang didampingi.

\section{f. Sarana religious lainnya dalam pendampingan}

Selain menggunakan Alkitab, pendamping pastoral juga perlu memahami penggunaan sarana keagamaan (religious resources) lainnya dalam mendampingi. Sarana keagamaan merupakan alat yang dipakai dalam pendampingan pastoral untuk menolong orang yang didampingi. Perlu diingat bahwa tidak ada kekuatan magis di dalamnya. Adapun sarana keagamaan yang dapat difungsikan dalam rangka memedulikan dan menolong adalah doa, meditasi, nyanyian atau musik, ziarah, ibadah, penumpangan tangan. Selain itu terdapat juga sarana lain yaitu minyak. Lilin, air, roti, anggur, bunga dan lain-lain. Penggunaan sarana keagamaan ini perlu cermat dan sebaiknya menggunakan satu sarana saja dalam setiap perjumpaan/pertemuan penampingan. Pendamping

\footnotetext{
${ }^{19}$ Beek, Pendampingan Pastoral. 38
} 
pastoral perlu tanggap akan hal ini sehingga tidak menimbulkan kebingungan bagi orang yang didampingi. Dalam mendampingi orang agar mampu mengampuni dan mampu menerima peristiwa yang kelam maka fungsi yang paling berperan dari pendampingan pastoral adalah fungsi menyembuhkan, walaupun berkaitan dengan fungsi-fungsi yang lain.

Fungsi menyembuhkan sangat penting secara khusus bagi mereka yang mengalami dukacita dan luka batin akibat kehilangan atau terbuang yang biasanya berakibat pada penyakit psikomatis. Ketidakmampuan mengampuni dan menerima peristiwa kelam merupakan wujud dari kedukaan yang dapat menyebabkan tekanan mental. Kepedulian dan kehadiran seorang pendamping pastoral akan menjadi obat penyembuh bagi mereka yang tertekan jiwanya. Dengan keterampilan dan sikap dasar yang dimiliki oleh pendamping pastoral maka mereka yang sulit mengampuni dapat terbuka hatinya untuk mengampuni sehingga penyakit psikologis yang menggerogoti tubuhnya dapat sembuh. Saat dia sudah sembuh, saat itulah dia akan merasakan kemerdekaan dari belenggu sakit hati, dendam, benci dan akar-akar pahit lainnya sehingga dapat berdaya guna dalam kehidupannya sehari-hari.

\section{KESIMPULAN}

Mengampuni (memaafkan) adalah revolusi cinta melawan ketidakadilan hidup. Ketika seseorang mengampuni, maka dengan begitu dia tidak memedulikan hukum normal alam yang mengajarkan tentang pembalasan atas sesuatu yang tidak selayaknya diterima. Pengampunan dapat dilakukan dengan meneladani sikap Yesus Kristus sang konselor sejati untuk memberikan kesembuhan yang holistik. Melalui pengampunan maka seseorang dapat menerima peristiwa kelam yang telah dialami di masa lalu. 


\section{DAFTAR PUSTAKA}

Beek, Aart Van. Pendampingan Pastoral. Jakarta: Gunung Mulia, 2015.

Bergant, Dianne, Robert J. Karris (editor). Tafsir Alkitab Perjanjian Baru. Yogyakarta: Kanasius, 2002.

Clinebell, Howard. Tipe-Tipe Pendampingan Pastoral Dan Konseling Pastoral. Jakarta: Gunung Mulia, 2002.

Hill, Harriet. Healing the Wounds Of Trauma: How The Church Can Help. Philadelphia: American Bible Society, 2016.

J.L. Ch, Abineno. Pelayanan Pastoral Kepada Orang Berduka. Jakarta: Gunung Mulia, 2007.

Meehan, Bridget Mary. Kuasa Penyembuhan Doa. Yogyakarta: Kanasius, 2006.

Siswanto. Kesehatan Mental: Konsep, Cakupan Dan Pengembangannya. Yogyakarta: Gunung Mulia, 2007.

Wiryasaputra, Totok S. Pendampingan Pastoral Orang Sakit. Yogyakarta: Kanasius, 2016.

—. Pengantar Konseling Pastoral. Yogyakarta: Diandra, 2014.

“Kamus Besar Bahasa Indonesia (KBBI).” Jakarta: Balai Pustaka, 1996. 